\title{
Epithelial remodelling of the midgut in the post-embryonic development of Partamona helleri (Apidae, Meliponini)
}

\author{
Renan dos Santos Araujo ${ }^{1}$, Kenner Morais Fernandes ${ }^{2}$, Marcos Pereira Lopes ${ }^{1}$, \\ Gustavo Ferreira MARTins $^{2}$, Mara Garcia TAVAREs ${ }^{2}$ \\ ${ }^{1}$ Programa de Pós-graduação em Biologia Celular e Estrutural, Departamento de Biologia Geral, Universidade Federal de \\ Viçosa, Viçosa, MG 36570-000, Brazil \\ ${ }^{2}$ Departamento de Biologia Geral, Universidade Federal de Viçosa, Viçosa, MG 36570-000, Brazil
}

Received 4 July 2018 - Revised 25 September 2018 - Accepted 19 November 2018

\begin{abstract}
In this work, we describe the changes that occur in the midgut during metamorphosis of Partamona helleri, a species of stingless bees found in Neotropical regions. Morphology and immunofluorescence data were analysed in larvae, pupae and adults. The intestinal epithelium presented morphological variations between the different stages of development, including the size of the striated border. Cells undergoing apoptosis and autophagy were observed in practically all stages, with the autophagy process prevailing over apoptosis in most stages, except in post-defecating larvae. The quantity of cells in oxidative stress increased in the pupae stage, especially in the black-eyed and pink-eyed pupae, and decreased in the adult stage. Cell proliferation, on the other hand, was more evident in black-eyed pupae, mainly in the stage with the highest number of cells in autophagy. In general, the results contributed to a better understanding of morphogenesis of the stingless bee digestive system.
\end{abstract}

\section{stingless bees / apoptosis / autophagy / cell proliferation / oxidative stress}

\section{INTRODUCTION}

The midgut of insects is the main organ responsible for food digestion and the absorption of nutrients. In the midgut epithelium, including that of bees, there are three major cell types: endocrine cells, which produce and secrete peptides with endocrine functions; digestive cells, which perform the digestion and absorption of food; and regenerative cells or stem cells, responsible for cell renewal and remodelling of the epithelium (Serrão and Cruz-Landim 1996; Martins et al. 2006; Malaspina and Silva-Zacarin 2006; Cruz et al. 2007, 2011; Nagy et al. 2018).

Corresponding author: R. Araujo, renan.s.araujo@ufv.br

Manuscript editor: Monique Gauthier
During pupation, the midgut of the bees is remodelled. This allows the adaptation of the bee to adult life, especially when considering the different eating habits of larvae and adults (Neves et al. 2002). The remodelling of the intestinal epithelium of bees begins in the last larval stage, mainly involving the processes of cell death, proliferation and cellular differentiation (CruzLandim and Mello 1970; Neves et al. 2002; IllaBochaca and Montuenga 2006; review in Hakim et al. 2010; Gonçalves et al. 2017). In this process of remodelling, the differentiated cells of the larva degenerate and are replaced, in the pre-pupal stage, by regenerative cells that differentiate and reorganise to form the adult individual's epithelium (Neves et al. 2003a, b; Martins et al. 2006; Cruz et al. 2011).

Research carried out with the purpose of understanding the remodelling of intestinal epithelium of stingless bees during metamorphosis used 
the species Melipona quadrifasciata as a model (Cruz-Landim and Mello 1970; Neves et al. 2002, 2003a, b; Cruz-Landim and Cavalcante 2003; Martins et al. 2006; Fernandes et al. 2010; Cruz et al. 2011, 2013). The remodelling of the midgut epithelium of $M$. quadrifasciata involves the proliferation of regenerative cells and the expansion of these cells during cell differentiation. High mitotic rates were detected in this species in pink-eyed pupae, followed by an increase in the number of regenerative cells in black-eyed pupae (Cruz et al. 2013). Although remodelling of the midgut during the metamorphosis of $M$. quadrifasciata has been studied, similar studies with other species of stingless bees, such as those of the genus Partamona, have not yet been performed, meaning that interspecific comparisons of this process are not possible.

The genus Partamona groups 33 species present in the Neotropical region, from the south of Brazil to Mexico (Silvia and Camargo 2003; Fernandes et al. 2017; Miranda et al. 2017). Partamona helleri, for example, can be found in Brazil, in the states of Bahia, Espírito Santo, Minas Gerais, Paraná, Rio de Janeiro, Santa Catarina and São Paulo (Camargo and Pedro 2013). Despite being an aggressive species, $P$. helleri plays an important economic role as a pollinator of a large number of plant species (Bernardes et al. 2018). This ensures the maintenance and conservation of natural ecosystems and economically relevant agricultural systems (McGregor 1976; Camargo and Pedro 2013).

Partamona helleri has been used as a model in studies of flight activities (Teixeira and Campos 2005), nesting (Batista et al. 2003; Camargo and Pedro 2003; Couvillon et al. 2007), genetic variability (Francisco et al. 2006; Marthe et al. 2007; Brito and Arias 2010), karyotyping and the analysis of B chromosomes (Tosta et al. 2007; Martins et al. 2009), the effects of habitat fragmentation and the impact of insecticide on different parameters, including survival and behaviour (Antonini et al. 2013; Tomé et al. 2015). To expand knowledge on the biology of $P$. helleri, the present work describes the changes that occur in the midgut epithelium during post-embryonic development, involving autophagy, apoptosis, cell proliferation and oxidative stress. The data obtained will increase knowledge of the biology of the Meliponini bee species.

\section{MATERIAL AND METHODS}

\subsection{Biological material}

The specimens of Partamona helleri (workers) were collected in nests kept in the Central Apiary of the Federal University of Viçosa $\left(20^{\circ} 75^{\prime} \mathrm{S} 42^{\circ}\right.$ $86^{\prime} \mathrm{W}$ ), in the State of Minas Gerais, Brazil. The following stages of development were used: larvae (pre-defecating and post-defecating), pupae (whiteeyed, pink-eyed and black-eyed) and adult (newly emerged-greyish colour and forager-black colour).

\subsection{Histology}

The midgut of each sample was dissected in saline solution $\left(\mathrm{NaCl} 0.1 \mathrm{M}, \mathrm{KH}_{2} \mathrm{PO}_{4} 20 \mathrm{mM}\right.$ and $\mathrm{Na}_{2} \mathrm{HPO}_{4} 20 \mathrm{mM}$ ) and fixed in Zamboni solution (paraformaldehyde at $2 \%$, containing $15 \%$ picric acid in $0.1 \mathrm{M}$ sodium phosphate buffer) for $2 \mathrm{~h}$. Subsequently, the samples ( $n=5$ for each stage) were washed three times in PBS (phosphate buffered saline, $0.1 \mathrm{M}$ ), dehydrated in a gradual series of ethanol (70, 80, 90, 95 and 99\%), embedded in historesin (Leica Biosystems, São Paulo, SP, Brazil) and sectioned.

The 7- $\mu \mathrm{m}$ thick sections were stained with haematoxylin and eosin and photographed under an Olympus BX53 coupled to the Olympus DP73 digital camera (Olympus Corp., Tokyo, Japan). The height of the striated border was quantified using Image-Pro Plus 4.5 software (Media Cybernetics, Silver Spring, EUA). For this quantification, six images with a $40 \times$ objective (total area $=$ $0.414 \mathrm{~mm}^{2}$ ) from each of the seven stages were arbitrarily selected and the means and standard deviations were measured.

\subsection{Immunofluorescence}

The samples, fixed as described above, were washed three times with PBS and incubated in $0.1 \mathrm{M}$ PBS $/ 1 \%$ Triton X-100 (PBST) for $2 \mathrm{~h}$. Then, the samples were incubated (overnight at 
$4{ }^{\circ} \mathrm{C}$ ) separately with the following primary antibodies, diluted in PBS: cleaved anti-caspase-3 (Sigma-Aldrich, St. Louis Mo., EUA; 1:500); anti-LC3 A/B (Cell Signalling Technology, Beverly, MA, EUA; 1:100); protein anti-phosphohistone H3 [(PH3) (Cell Signalling Technology, Beverly, MA, EUA; 1:500)]; and anti-peroxidase (Sigma-Aldrich, St. Louis Mo., EUA; 1:500), to reveal apoptosis, autophagy, cell proliferation and oxidative stress, respectively. The four treatments were performed in triplicate, therefore using 12 samples from each stage.

Subsequently, the midgut was washed and incubated with TRITC-conjugated secondary antibody (Thermo Fisher-Scientific, Waltham, Mass., EUA; 1:500) in PBS overnight at $4{ }^{\circ} \mathrm{C}$. After being subjected to the triple wash, the organs were stained with diamidino-2-phenylindole (DAPI; Biotium, Inc., Hayward, CA, EUA; 1:500) for $30 \mathrm{~min}$. Finally, total assemblies with whole intestines on histological slides were made using $50 \%$ sucrose solution and analysed under an Evos® FL fluorescence microscope (Advanced Microscopy Group, Bothell, WA, USA). For the negative control, three midguts from each stage of development were treated as described previously, except for treatment with the primary antibodies.

The treatments with anti-caspase-3, anti-LC3 $\mathrm{A} / \mathrm{B}$ and anti-phospho-histone $\mathrm{H} 3$ were performed as proposed by Cruz et al. (2013) and Gonçalves et al. (2017) for M. quadrifasciata and Apis mellifera, respectively, while treatment with anti-peroxidase was standardised for P. helleri from the method proposed by Lopes et al. (2018) for A. mellifera .

\subsection{Statistical analysis}

The total number of intestinal cells labelled with each of the above-mentioned antibodies was quantified in the superficial area of the midgut at each stage in the visible field of the microscope $\left(1.656 \mathrm{~mm}^{2}\right)$. The data were submitted to normality test, one-way analysis of variance (ANOVA) and Tukey's test, at $5 \%$ probability, comparing the different stages between them. These analyses were performed using SAS software (v. 9.0) for Windows (SAS Institute 2002).

\section{RESULTS}

\subsection{Morphology of the intestinal epithelium}

The midgut epithelium of $P$. helleri workers, in all of the analysed stages, presented digestive cells and regenerative cells attached to the basal membrane and also longitudinally-organised muscle fibres. In pre- and post-defecating larvae, the epithelium was pseudostratified and comprised of a layer of columnar digestive cells and regenerative cells (of smaller size), located between the digestive cells (Figure 1A, B). The apical region of the digestive cells had a clearly visible striated border in the predefecating larvae $(4.41 \pm 2.12 \mu \mathrm{m})$ and reduced in the post-defecating larvae $(1.31 \pm 0.14 \mu \mathrm{m})$. In the post-defecating larvae, regenerative cell nuclei were larger compared to pre-defecating larvae and cell debris was detected in the intestinal lumen, due to the disintegration of the epithelium.

The intestinal epithelium in the pupal phase was more organised than in the previous stages. In white-eyed pupae, the digestive cells were juxtaposed columnar and the regenerative cells were between them (Figure 1C). The striated border of the digestive cells was well developed (7.20 \pm $2.45 \mu \mathrm{m})$. Additionally, the muscle cell layer was more prominent and the amount of cellular debris in the lumen was lower than in postdefecating larvae. From this stage, the nuclei of the epithelial (digestive and regenerative) cells were shown to be more rounded than the cellular nuclei of the larvae (pre- and post-defecating). The midgut epithelium of pink-eyed pupae also contained columnar digestive cells, but with a less striated border $(2.32 \pm 0.68 \mu \mathrm{m})$ than that observed in white-eyed pupae and less evident cellular debris (Figure 1D). Black-eyed pupae, on the other hand, although also presenting columnar digestive cells, presented regenerative cells organised in nests of different sizes. At this stage, it was also possible to observe a well-developed striated border in the apical regions of the epithelium $(12.54 \pm 1.44 \mu \mathrm{m})$ and also degenerating cells. In addition, the amount of cellular debris in the intestinal lumen was greater than in the two preceding stages (Figure 1E).

In the adult phase, the midgut epithelial structure of newly emerged and forager was similar. At 

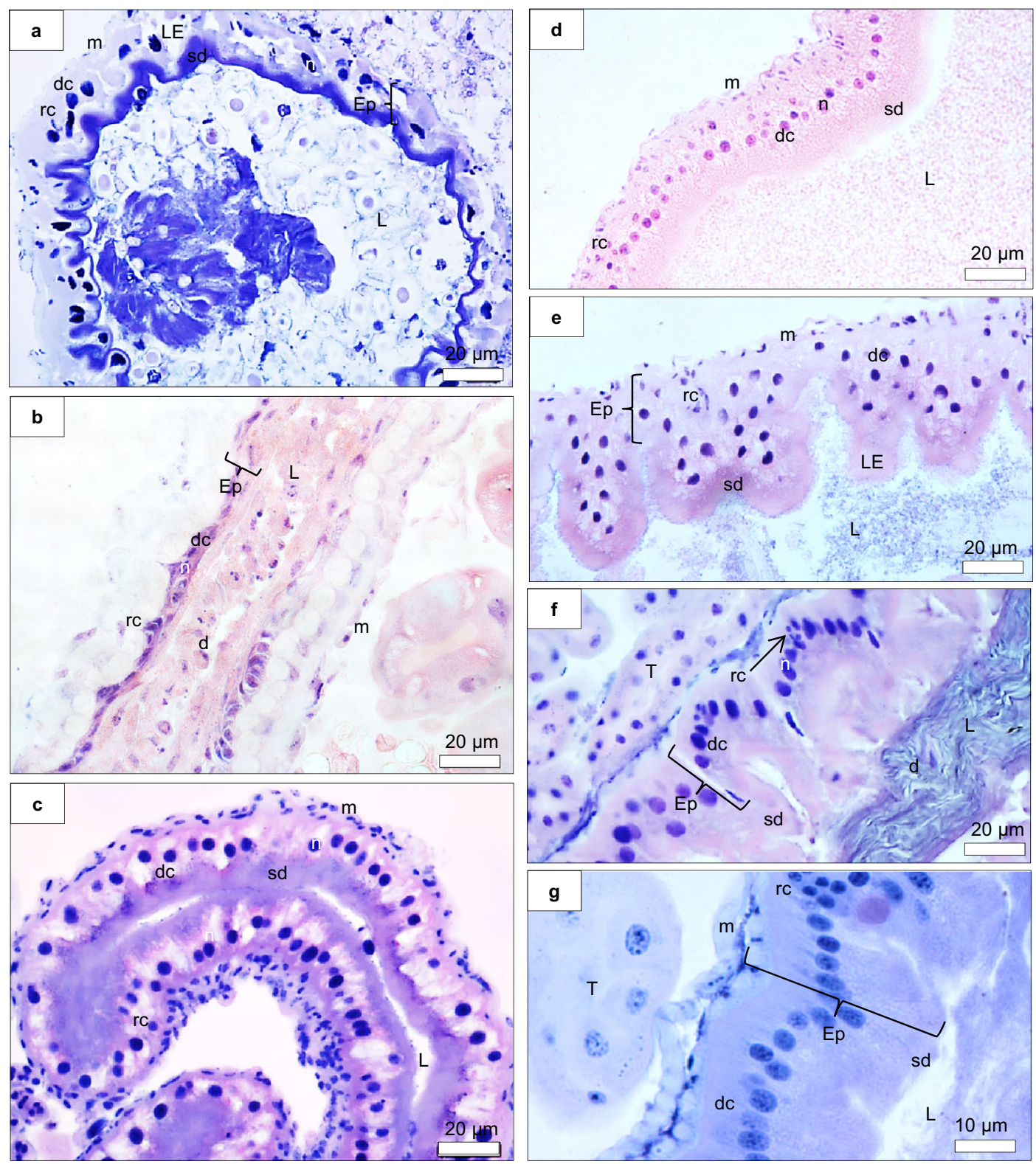

Figure 1 Histological sections of $P$. helleri midgut stained with haematoxylin and eosin: A Pre-defecating larvae; B post-defecating larvae; $\mathbf{C}$ white-eyed pupae; D pink-eyed pupae; $\mathbf{E}$ black-eyed pupae; $\mathbf{F}$ newly emerged adult; $\mathbf{G}$ forager adult. In the midgut epithelium (Ep), located near a layer of muscle cells (m), the digestive (dc) and regenerative cells (rc) are shown with their nuclei (n) evident. In the apical region of the digestive cells is the striated border (sd) and cell debris (d) is observed in the intestinal lumen (L), mainly resulting from the degeneration of the epithelium (LE). Note that it is possible to find Malpighian tubules (T) near the epithelium.

these stages, the intestinal epithelium showed a reorganisation process similar to that of blackeyed pupae. Regenerative cells remained grouped in nests between the basement membrane and the digestive cells, which were well differentiated and of the columnar type (Figures 1F, G). These digestive cells had striated borders varying from $3.67 \pm 0.97 \mu \mathrm{m}$ (newly emerged) to $4.98 \pm$ 
$1.36 \mu \mathrm{m}$ (adult foragers). Both cell types had ovoid nuclei. In the lumen of the intestinal epithelium of newly emerged adults, the abundance of cellular debris was greater than in pupae (whiteeyed, pink-eyed and black-eyed) and foragers.

\subsection{Apoptosis, autophagy, proliferation and oxidative stress in intestinal cells}

In $P$. helleri, apoptosis of cells of the midgut was initiated in post-defecating larvae. At this stage, 6 cells marked with caspase- 3 were observed in the analysed individuals $\left(\mathrm{F}_{2,20}=20.39\right.$; $P<0.001$, Figure 2A). This process increased in white-eyed pupae ( 9 cells), decreased significantly in pink-eyed pupae and black-eyed pupae (2 cells, $P<0.05)$ and increased again in newly emerged adults ( 3 cells). In the forager workers, the number of cells undergoing apoptosis decreased again (1 cell). Nevertheless, these data were not significant in comparison to the newly emerged workers $(P>0.05)$.

Cells positive for LC3 A/B, indicating autophagy, were detected in all stages analysed (Figures 2B and 3); however, in the white-eyed pupae (28 cells on average) and black-eyed pupae (50 cells on average), significant increases in the numbers of these cells were observed in comparison with the other stages $\left(\mathrm{F}_{2,20}=10.4 ; P<0.002\right)$.

Regarding cell proliferation, a small number of PH3-positive cells were detected in the stages of pre- and post-defecating larvae; however, a significant increase was observed in the number of these cells in the stages of white-eyed pupae (28 cells), pink-eyed pupae (26 cells) and mainly black-eyed pupae (79 cells) $\left(\mathrm{F}_{2,20}=73.43 ; P<\right.$

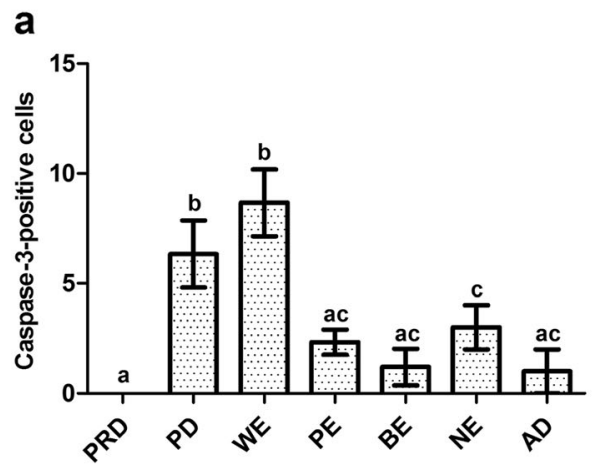

b

C
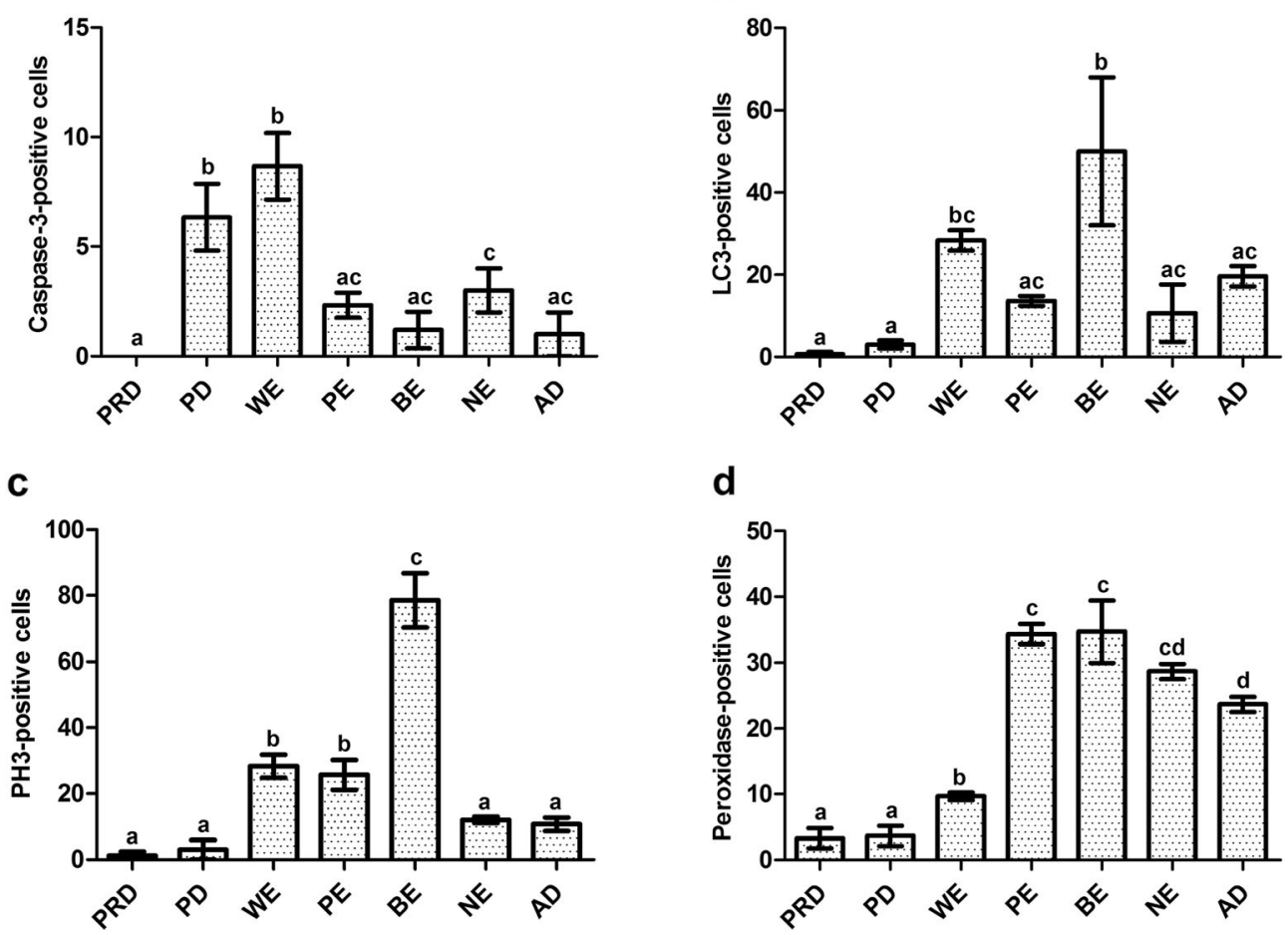

d

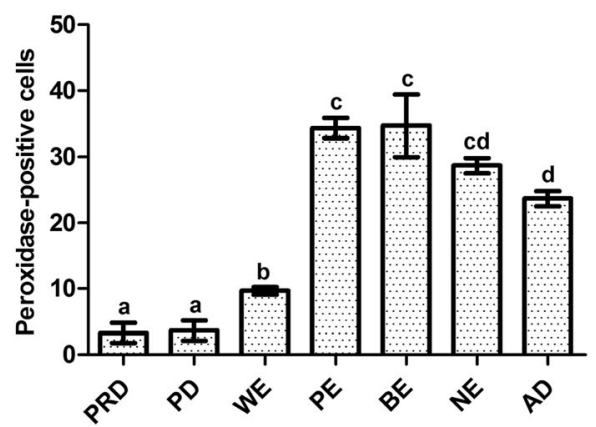

Figure 2 Mean number of marked cells by measurement field (total area $=1.656 \mathrm{~mm}^{2}$ ) in the midgut of $P$. helleri for different proteins: A Caspase-3-positive; B LC3 A/B-positive; C PH3-positive; D Peroxidase-positive. PRD, predefecating larvae; PD, post-defecating larvae; WE, white-eyed pupae; PE, pink-eyed pupae; BE, black-eyed pupae; $\mathrm{NE}$, newly emerged adults; AD, forager adults. Different letters denote significant differences in relation to other stages $(P<0.05)$. 
Caspase-3

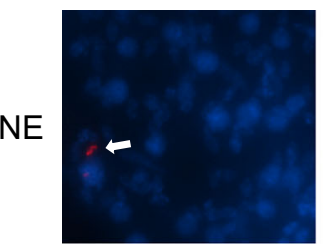

$\downarrow$

$A D$

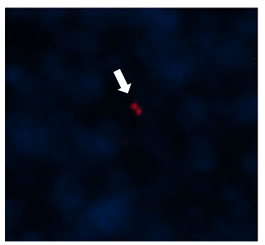

LC3 A/B
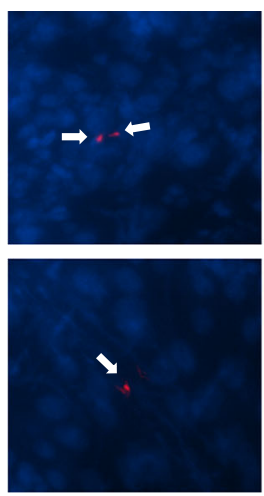

$\mathrm{PH} 3$
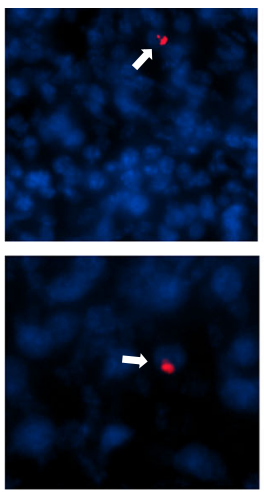

Peroxidase
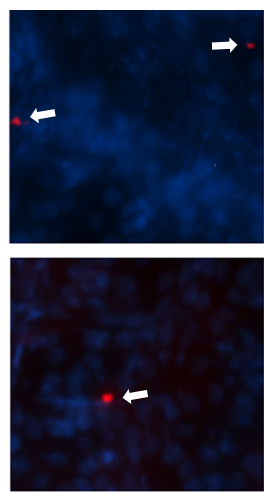

Negative control
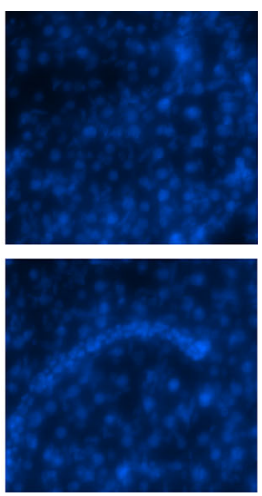

$100 \mu \mathrm{m}$

Figure 3 Representative total assembly of the midgut of $P$. helleri evidencing the positive markings for: caspase, LC3 A/B, phospho-histone H3 (PH3) and peroxidase in adult individuals. The cell nuclei are stained in blue (DAPI) and the positive markings for the different antibodies are in red (arrows). NE, newly emerged adults and AD, forager adults.

0.0001). Thereafter, there was a significant reduction in the adult phase: $12 \mathrm{PH} 3$-positive cells in newly emerged and 11 in foragers $(P<0.05$, Figures 2C and 3).

Peroxidase-positive cells were also reported at all of the stages analysed (Figure 2D). It was possible to detect, however, a significant increase in the number of these cells in the white-eyed pupae (10 cells) in relation to the previous stage (4 cells) and in the stage of pink-eyed pupae (34 cells) and black-eyed pupae (35 cells) in relation to white-eyed pupae $\left(\mathrm{F}_{2,20}=85.72, P<0.0001\right)$. Although the number of labelled cells remained relatively high in the newly emerged adults and foragers (29 and 24 cells, respectively, Figure 3), it was significantly lower in the foragers compared to the stages of pink-eyed pupae and black-eyed pupae $(P<0.05)$.

\section{DISCUSSION}

The midgut epithelium undergoes extensive remodelling during post-embryonic development of holometabolous insects, so that individuals can adapt to the adult phase (Romanelli et al. 2016; Malta et al. 2017). Our data showed that the midgut of $P$. helleri presented significant epithelial degradation in post-defecating larvae, including the striated border of the digestive cells; however, from the stage of white-eyed pupae onwards, the epithelium was reorganised and the border reconstituted. This reconstitution resembles that observed in the intestinal epithelium of Drosophila melanogaster, where the striated border also undergoes a radical structural change during post-embryonic development, as evidenced by the presence of large secretory vesicles within the apical region of the microvilli and the reduced lumen volume in the larval moult $(\mathrm{Li}$ et al. 2009). The variation in the size of the striated border may be associated with the degree of cellular uptake, that is, the larger the size, the greater the capacity of the intestinal cells to absorb nutrients (Gonçalves et al. 2013, 2014). In view of this, we can speculate that the prominence of the striated border observed in white-eyed pupae and black-eyed pupae is related to the absorption of cellular debris caused by autophagy, because these were the stages where the largest numbers of LC3 A/B-positive cells were detected. In addition, the reduction of the striated border of pinkeyed pupae coincided with the reduction of the number of cells in autophagy. These data, therefore, corroborate the evidence that the midgut continues to exhibit metabolic activity during metamorphosis (Franzetti et al. 2016). 
Our data further confirm that cell death of the midgut epithelium in P. helleri occurs by the joint action of the mechanisms of apoptosis and autophagy, with the latter being predominant in most of the stages studied here, except in postdefecating larvae. After this stage, and especially in black-eyed pupae, the number of cells in autophagy increased, whereas few cells in apoptosis were observed in black-eyed pupae and in adults. Similarly, many autophagic vesicles were found in the digestive cells in pre-pupae of Melipona quadrifasciata, which subsequently separate and are released into the lumen of the midgut (Neves et al. 2003a, b); however, no apoptosis was detected in cells of the midgut in black-eyed pupae or in adults of this species (Cruz et al. 2013). These data, therefore, suggest that although apoptosis is considered crucial for the removal of excess and unwanted cells from organs during post-embryonic development (Ulukaya et al. 2011), the autophagy process may be the main cause of cell death in the midgut epithelium in the pupal stage of $P$. helleri and, perhaps, in stingless bees in general. This may occur because, as the insect does not consume more water or food after defecation, autophagy of the larval cells and subsequent recycling of residues may provide a plausible strategy for obtaining the necessary means for the regeneration and construction of structures of the pupal and adult epithelium (Franzetti et al. 2012).

The proliferation of regenerative cells, in turn, as observed in the present study, had already been reported in the midgut of larvae, pre-pupae and pupae of M. quadrifasciata (Martins et al. 2006; Cruz et al. 2011, 2013). The analyses carried out confirmed that regenerative cells in bees initiate the differentiation process and the formation of digestive cells in the pre-pupal stage (Neves et al. 2003a, b). They also demonstrated, for the first time, that the process of cell proliferation also occurs in adult Meliponini individuals; however, even under these conditions, the reestablishment of new nests of regenerative cells to promote midgut renewal during the adult stage occurs in black-eyed pupae (Cruz et al. 2013), because the number of PH3-positive cells at this stage was much higher than that found in both newly emerged and forager adults.
The largest number of PH3-positive cells observed in $P$. helleri black-eyed pupae may be to compensate for the high number of cells undergoing cell death that were observed at this stage (mainly by autophagy), thus contributing to the restructuring of the intestinal epithelium. In addition, the significant decrease in PH3-positive cells in adults is in accordance with the reduction of LC3 A/B-positive cells, that is, it appears that the cellular events of proliferation and autophagy are related, occurring simultaneously, as suggested in other insects (Romanelli et al. 2014; Franzetti et al. 2015; Nagy et al. 2018).

Comparing the different stages, the immunolabelling analyses used showed several peroxidase-positive cells in the stages of pink and black-eyed pupa, precisely the stages in which death and proliferation cellular were evident. Thus, considering these results, it may be suggested that activities related to the remodelling of the organ, in addition to several other factors, might cause oxidative stress in the cells and increase of antioxidant enzyme synthesis, to preserve organ homeostasis (Lopes et al. 2018). On the other hand, in adults, a significant reduction in the number of peroxidase-positive cells could be related to the decrease in autophagy and proliferation processes related to the remodelling of their digestive tract. Therefore, the variation in the number of peroxidase-positive cells in the midgut of $P$. helleri detected in the present study seems to be associated with the remodelling events that occur in this organ during the passage of the individual through the different stages of development; however, further studies are needed to understand why there is an increase in the number of peroxidase-positive cells at some stages in the post-embryonic development of the midgut.

The data from this study suggest, therefore, that during the remodelling of the midgut of $P$. helleri, the processes of apoptosis and autophagy occur during practically all stages of development, with autophagy being more evident than apoptosis in most of the analysed stages. While some cells enter the cell death pathway, others (regenerative cells) re-establish the epithelium, thus compensating for cell loss. These changes allowed the detection of oxidative stress in all of the stages analysed, but mainly in the pupal phase, in which 
the events of apoptosis and autophagy were more evident. Together, these data contribute to a better understanding of the development of the stingless bee digestive system.

\section{ACKNOWLEDGEMENTS}

The authors thank at the Central Apiary at the Federal University of Viçosa for technical assistance.

\section{AUTHORS' CONTRIBUTIONS}

$\mathrm{RA}, \mathrm{KF}$ and ML conceived this research and designed experiments; RA and MT participated in the design and interpretation of the data; RA, ML and KF performed experiments and analysis; RA, MT and GM wrote the paper and participated in the revisions of it. All authors read and approved the final manuscript.

\section{FUNDING}

This study was funded by Coordenação de Aperfeiçoamento de Pessoal de Nível Superior Brasil (CAPES) - Finance Code 001, Conselho Nacional de Desenvolvimento Científico e Tecnológico (CNPq) and Fundação de Amparo à Pesquisa do Estado de Minas Gerais (FAPEMIG).

\section{COMPLIANCE WITH ETHICAL STANDARDS}

Conflict of interest The authors declare that they have no potential conflict of interest in relation to the study in this paper.

Renouvellement épithéliale de l'intestin moyen dans le développement post-embryonnaire de Partamona helleri (Apidae, Meliponini)

Abeille sans dard / apoptose / autophagie / prolifération cellulaire / stress oxydatif

Erneuerung des Mitteldarmepithels in der Postembryonalphase von Partamona helleri (Apidae, Meliponini)

Stachellose Bienen / Apoptosis / Autophagie / Zellteilung / oxidativer Stress
Publisher's Note Springer Nature remains neutral with regard to jurisdictional claims in published maps and institutional affiliations.

\section{REFERENCES}

Antonini, Y., Martins, R. P., Aguiar, L. M., Loyola, R. D. (2013) Richness, composition and trophic niche of stingless bee assemblages in urban forest remnants. Urban Ecosyst. 16, 527-541.

Batista, M. A., Ramalho, M., Soares, A. E. E. (2003) Nesting sites and abundance of Meliponini (Hymenoptera: Apidae) in heterogeneous habitats of the Atlantic Rain Forest, Bahia, Brazil. Lundiana 4 (1), 19-23.

Bernardes, R. C., Barbosa, W. F., Martins, G. F., Lima, M. A. P. (2018) The reduced-risk insecticide azadirachtin poses a toxicological hazard to stingless bee Partamona helleri (Friese, 1900) queens. Chemosphere 201, 550-556.

Brito, R. M., Arias, M. C. (2010) Genetic structure of Partamona helleri (Apidae, Meliponini) from Neotropical Atlantic rainforest. Insect. Soc. 57, 413-419.

Camargo, J. M., Pedro, S. R. (2003) Meliponini neotropicais: o gênero Partamona Schwarz, 1939 (Hymenoptera, Apidae, Apinae) - bionomia e biogeografia. Rev. Bras. Ent. 47 (3), 311-372.

Camargo, J. M., Pedro, S. R. (2013) Meliponini Lepeletier, 1836. In Moure, JS., Urban D \& Melo GAR (Orgs). Catalogue of Bees (Hymenoptera, Apoidea) in the Neotropical Region - online version. Available at http://www.moure.cria.org.br/catalogue (accessed on 03 April, 2018)

Couvillon, M. J., Wensellers, T., Imperatriz-Fonseca, V. L., Nogueira-Neto, P., Ratnieks, F. L. W. (2007) Comparative study in stingless bees (Meliponini) demonstrates that nest entrance size predicts traffic and defensivity. J. Evol. Biol. 2, 194-201.

Cruz, L. C., Araujo, V. A. Dolder, H., Neves, C. A. (2007) Midgut ultrastructure of queens and foraging workers of Melipona quadrifasciata anthidioides (Hymenoptera, Apidae, Meliponini). Sociobiology 50, 11171125.

Cruz, L. C., Araújo, V. A., Dolder, H., Araújo, A. P., Serrão, J. E., Neves, C. A. (2011) Morphometry of the midgut of Melipona quadrifasciata anthidioides (Lepeletier) (Hymenoptera: Apidae) during metamorphosis. Neotrop Entomol. 40 (6), 677-681.

Cruz, L. C., Araújo, V. A., Fialho, M. C. Q., Serrão, J. E., Neves, C. A. (2013) Proliferation and cell death in the midgut of the stingless bee Melipona quadrifasciata anthidioides (Apidae, Meliponini) during metamorphosis. Apidologie, 44, 458-66.

Cruz-Landim, C., Cavalcante, V. M. (2003) Ultrastructural and cytochemical aspects of metamorphosis in the midgut of Apis mellifera L. (Hymenoptera: Apidae: Apinae). Zool. Sci. 20 (9), 1099-1107. 
Cruz-Landim, C., Mello, M. L. S. (1970) Post-embryonic changes in Melipona quadrifasciataanthidioides Lep. IV. Development of the digestive tract (1). Boletim do Instituto de Biociências daUniversidade de São Paulo. Nova Série, Zoologia e Biologia Marinha, 27 (27), 229-263.

Fernandes, K. M., Araújo, V. A., Serrão, J. E., Martins, G. F., Campos, L. A. O., Neves, C. A. (2010) Quantitative analysis of the digestive and regenerative cells of the midgut of Melipona quadrifasciata anthidioides (Hymenoptera: Apidae). Sociobiology 56 (2), 489-505.

Fernandes, C. R. M., Almeida, A. B., Del Lama, M. A., Martins, C. F. (2017) Nesting substrate characteristics of Partamona seridoensis Pedro \& Camargo (Hymenoptera: Apidae) in areas of dry forest in Brazil. Sociobiology 64 (1), 26-32.

Francisco, F. O., Brito, R. M., Arias, M. C. (2006) Alelle number and heterozigosity for microsatellite loci in different stingless bee species (Hymenoptera: Apidae, Meliponini). Neot. Ent. 35 (5), 638-643.

Franzetti, E., Huang, Z. J., Shi, Y. X., Xie, K., Deng, X. J., Li, Q. R., Yang, W. Y., Zeng, W. N., Casartelli, M., Deng, H. M. (2012) Autophagy precedes apoptosis during the remodeling of silkworm larval midgut. Apoptosis 17, 305-324.

Franzetti, E., Romanelli, D., Caccia, S., Cappellozza, S., Congiu, T., Rajagopalan, M., Grimaldi, A., Eguileor, M., Casartelli, M., Tettamanti, G. (2015) The midgut of the silkmoth Bombyx mori is able to recycle molecules derived from degeneration of the larval midgut epithelium. Cell Tissue Res. 361, 509-528.

Franzetti, E., Casartelli, M., D'Antona, P., Montali, A., Romanelli, D., et al. (2016) Midgut epithelium in molting silkworm: A fine balance among cell growth, differentiation, and survival. Arth. Struc. Develop. 45, 368-379.

Gonçalves, W. G., Fernandes, K. M., Gonçalves, M. P., Martins, G. F., Zanuncio, J. C., Serrão, J. E. (2013) The midgut of the parasitoid Campoletis flavicincta (Hymenoptera: Ichneumonidae). Flor. Ent. 96 (3), 10161022.

Gonçalves, W. G., Fernandes, K. M., Barcellos, M. S., Silva, F. P., Magalães-Jr, M. J., Zanuncio, J. C., Martins, G. F., Serrão, J. E. (2014) Ultrastructure and Immunofluorescence of the midgut of Bombus morio (Hymenoptera: Apidae: Bombini). C. R. Biologies. 337 (6), 365-372.

Gonçalves, W. G., Fernandes, K. M., Santana, W. C., Martins, G. F., Zanuncio, J. C., Serrão, J. E. (2017) Post-embryonic changes in the hindgut of honeybee Apis mellifera workers: Morphology, cuticle deposition, apoptosis, and cell proliferation. Dev. Biol. 431, 194-204.

Hakim, R. S., Baldwin, K., Smagghe, G. (2010) Regulation of midgut growth, development, and metamorphosis. Annu. Rev. Entomol. 55, 593-608.

Illa-Bochaca, I., Montuenga, L.M. (2006) The regenerative nidi of the locust midgut as a model to study epithelial cell differentiation from stem cells. J. Exp. Bio. 209, 2215-2223.
Li, H. M., Sun, L., Mittapalli, O., Muir, W. M., Xie, J., Wu, J., Schemerhorn, B. J., Sun, W., Pittendrigh, B. R., Murdock, L. L. (2009) Transcriptional signatures in response to wheat germ agglutinin and starvation in Drosophila melanogaster larval midgut. Ins. Mol. Bio. 18 (1), 21-31.

Lopes, M. P., Fernandes, K. M., Tomé, H. V. V., Gonçalves, W. G., Miranda, F. R., Serrão, J. E., Martins, G. F. (2018) Spinosad-mediated effects on the walking abilities, midgut, and Malpighian tubules of Africanized honey bee workers. Pest Management Science, https://doi.org/10.1002/ps.415.

Malaspina, O., Silva-Zacarin, E. C. M. (2006) Cell markers for ecotoxicological studies in target organs of bees. Braz. J. Morphol. Sci. 23 (3-4), 303-309.

Malta, J., Heerman, M., Weng, J. L., Fernandes, K. M., Martins, G. F., Ramalho-Ortigão, M. (2017) Midgut morphological changes and autophagy during metamorphosis in sand flies. Cell Tissue Res. 368, 513-529.

Marthe, J. B., Tavares, M. G., Campus, L. A. O. (2007) Genetic variability in Partamona helleri (Hymenoptera: Apidae) populations with and without B chromosomes. Biosc. J. 23, 52-57.

Martins, G. F., Neves, C. A., Campos, L. A. O., Serrão, J. E. (2006) The regenerative cells during the metamorphosis in the midgut of bees. Micron 37, 161-168.

Martins, C. C. C., Duarte, O. M. P., Waldschmidt, A. M., Alves, R. M. D. O., Costa, M. A. (2009) New occurrence of B chromosomes in Partamona helleri (Friese, 1900) (Hymenoptera, Meliponini). Gen. Mol. Bio. 32 (4), 782-785.

McGregor, S. E. (1976) Insect pollination of cultivated crop plants (Vol. 496). Washington, DC:Agricultural Research Service, US Department of Agriculture.

Miranda, E. A., Ferreira, K. M., Carvalho, A. T., Martins, C. F., Fernandes, C. R., Del Lama, M. A. (2017) Pleistocene climate changes shaped the population structure of Partamona seridoensis (Apidae, Meliponini), an endemic stingless bee from the Neotropical dry forest. PloS One 12 (4), 1-13.

Nagy, P., Sándor, G. O., Juhász, G. (2018) Autophagy maintains stem cells and intestinal homeostasis in Drosophila. Sci. Rep. 8, 1-9.

Neves, C. A., Gitirana, L. B., Serrão, J. E. (2002) Ultrastructural study of the metamorphosis in the midgut of Melipona quadrifasciata anthidioides (Apidae, Meliponini) worker. Sociobiology, 41 (1), 443-459.

Neves, C. A., Serrão, J. E., Gitirana, L. B. (2003a) FMRFamide-like immunoreacteve endocrine cells in differente castes of Melipona quadrifasciata anthidioides (Apidae; Meliponini). Braz. J. Mor. Sci. 20 (3), 157-164.

Neves, C. A., Gitirana, L. B., Serrão, J. E. (2003b) Ultrastructure of the Midgut Endocrine Cells in Melipona quadrifasciata anthidioides (Hymenoptera, Apidae). Braz. J. Biol. 63 (4), 683-690.

Romanelli, D., Casati, B., Franzetti, E., Tettamanti, G. (2014) A molecular view of autophagy in Lepidoptera. Biomed. Res. Int., https://doi.org/10.1155/2014/902315. 
Romanelli, D., Casartelli, M., Cappellozza, S., Eguileor, M., Tettamanti, G., 2016. Roles and regulation of autophagy and apoptosis in the remodelling of the lepidopteran midgut epithelium during metamorphosis. Sci. Rep. 6, 1-15.

SAS Institute 2002. The SAS System for Windows, Release 9.0. Cary, SAS Institute.

Serrão, J.E., Cruz-Landim, C. (1996) Microscopic observations of the digestion condition of pollen grains in the midgut of stingles bee larvae. J. Hym. Res. 5, 259263.

Silvia, R. M., Camargo, M. F. (2003) Meliponini neotropicais: o gênero Partamona Schwarz, 1939 (Hymenoptera, Apidae). Rev. Bras. Ent. 47, 1-117.

Teixeira, L. V., Campos, F. N. M. (2005) Stingless bees (Hymenoptera, Apidae) flight activity beginning: body size and ambient temperature influence. Rev. Bras. Zooc. 7 (2), 195-202.

Tomé, H. V. V., Barbosa, W. F., Correa, A. S., Gontijo, L. M., Martins, G. F., Guedes, R. N. (2015) Reduced-risk insecticides in Neotropical stingless bee species: impact on survival and activity. Annal. Appl. Bio. 166, 186-196.

Tosta, V. C., Tavares, M. G., Fernandes-Salomão, T. M., Barros, E. G., Campos, L. A. O., Camacho, J. P. M. (2007) Development of a SCAR marker for the analysis of B chromosome presence in Partamona helleri (Hymenoptera, Apidae). Cytogenet Genome Res. 116, 127-129.

Ulukaya, E., Acilan, C., Yilmaz, Y. (2011) Apoptosis: why and how does it occur in biology?. Cell Biochem. Funct. 29, 468-480. 